\title{
25 Research Soure \\ Effects of Ruminal Crabtree-negative Yeast Ensiled Rice Straw on Feed Intake, Rumen Fermentation, and Performance in Tropical Crossbred Lactating Holstein Cows
}

\author{
Chanon Suntara \\ Khon Kaen University \\ Anusorn Cherdthong ( $\square$ anusornc@kku.ac.th ) \\ Khon Kaen University \\ Suthipong Uriyapongson \\ Khon Kaen University \\ Metha Wanapat \\ Khon Kaen University \\ Pin Chanjula \\ Prince of Songkla University
}

\section{Research Article}

Keywords: Crabtree-negative yeast, ensiled rice straw, crossbred dairy cows, milk production, milk composition

Posted Date: January 15th, 2021

DOl: https://doi.org/10.21203/rs.3.rs-144298/v1

License: (c) (i) This work is licensed under a Creative Commons Attribution 4.0 International License.

Read Full License

Version of Record: A version of this preprint was published at Scientific Reports on March 18th, 2021. See the published version at https://doi.org/10.1038/s41598-021-85643-2. 


\section{Abstract}

This research aimed to determine the effects of ruminal Crabtree-negative yeast ensiled rice straw (RS) on feed intake, ruminal fermentation, milk production, and milk composition in tropical crossbred lactating Holstein cows. This study used 6 multiparous crossbreds between Holstein Frisian $\times$ Zebu dairy cows in their mid-lactation period (165.5 \pm 44.0 of day-in-milk) with an initial body weight of $363.9 \pm$ $55.80 \mathrm{~kg}$ (average milk yield $8.58 \mathrm{~kg} / \mathrm{d}$ ). Dairy cows were randomly allocated to three ensiled RS with various yeast species including $S$. cerevisiae, $P$. kudriavzevii KKU20, and $C$. tropicalis KKU20 according to a $3 \times 3$ replicated Latin square design. The ruminal yeasts were obtained by isolating, screening, and identifying the rumen of crossbred Thai-Holstein Friesian dairy cattle. The yeast species did not change the RS intake, concentrate diet, and total intake $(P>0.05)$. Crabtree-negative yeast $(P$. kudriavzevii and $C$. tropicalis) increased the apparent digestibility of dry matter by about $6.9 \%$ when compare with Crabtreepositive yeast (S. cerevisiae). Rumen $\mathrm{pH}$ and ammonia-nitrogen concentration were not changed among yeast species $(P>0.05)$. The bacterial populations at both 0 hours and 4 hours after feeding and the mean value were highest $(P<0.05)$ with ensiled RS with $C$. tropicalis KKU20. Ensiled RS with $P$. kudriavzevii KKU20 and $C$. tropicalis KKU20 were significantly increased with a total volatile fatty acids (VFAs) at 0 and 4 hours after feeding $(P<0.05)$ when compared with $S$. cerevisiae, whereas yeasts ensiled RS had no effect on the VFAs' profile $(P>0.05)$. The yeast strains' effects were not observed $(P>$ $0.05)$ on actual milk yields. The treatments did not alter the milk composition $(P>0.05)$; except for when the protein in the milk was highest in the $C$. tropicalis KKU20 fed group. In conclusion, $C$. tropicalis KKU20 could enhance the RS's nutrition value through increasing digestibility, the ruminal bacterial population, and total VFAs as well as could increase the milk protein.

\section{Introduction}

For several years, yeast has been the model organism used for enhancing animal efficiency and is the traditional practice for ruminant feed additives ${ }^{1}$. In many studies, using S. cerevisiae fermented with an agricultural by-product or rice straw (RS) has been shown to enhance their nutritional value, silage quality, and nutrient digestibility ${ }^{2,3}$. The baker's yeast, $S$. cerevisiae, rapidly converts molasses and urea to provide biomass and greater nutrients from whole cell when added with oxygen $\left(\mathrm{O}_{2}\right)$ during the proliferation process ${ }^{4}$. Wanapat et al. ${ }^{5}$ stated that $S$. cerevisiae significantly increases crude protein (CP) in feedstuff via cell proliferation during the fermentation process and it provides essential amino acids, particularly lysine and methionine, for dairy cattle. In addition, previous studies explained the benefit of live yeast in that it could provide the positive effect on feed utilization and performance production in the ruminants 6,7 .

Although $S$. cerevisiae has many benefits, several limitation have been reported, particularly that it produces low cell biomass ${ }^{8}$. Under aerobic conditions, S. cerevisiae exhibits alcoholic fermentation more than producing biomass. The "Crabtree-positive yeasts" are those that represent this characteristic 9 . Under excessive glucose and even aerobic conditions, Van Urk et al. ${ }^{10}$ revealed that $S$. cerevisiae had a 
limited proliferation capacity. Moreover, Wardrop et al. ${ }^{11}$ revealed that when cultivated with excessive glucose in a media solution, $S$. cerevisiae provides 7 times lower biomass compared to other strains. This phenomenon restricts the chances of animals to receive highly nutritious from yeast biomasses such as protein, essential amino acids, and vitamins. Therefore, it is important to extend the scope of research such as investigating different species that could solve this issue. However, yeasts that do not have the Crabtree effect can therefore generate greater biomass in aerobic culture than Crabtree-positive yeasts. These yeasts are called "Crabtree-negative yeasts" 9 .

Recently, newly isolated ruminal yeasts have been discovered ad are classified as Crabtree-negative yeasts that can generate high biomass. Suntara and Cherdthong ${ }^{8}$ reported that Candida tropicalis KKU20 and Pichia kudriavzevii KKU20 provide biomass more than S. cerevisiae by about $23.7 \%$ and 26.4 $\%$, respectively. Furthermore, both species were found able to release cellulase enzymes during the incubation time of about 0.022 to 0.101 unit/ml, respectively. In addition, $P$. kudriavzevii KKU20 can provide the maximum Carboxy methyl cellulase activity with the inoculant molasses $250 \mathrm{~g} / \mathrm{kg}$ and urea $30 \mathrm{~g} / \mathrm{kg}^{8}$. Similarly, Sarawan ${ }^{12}$ found that yeast isolated from the jasmine plant Candida konsanensis can release cellulase enzymes. Thus, yeast-producing cellulase enzymes might help to breakdown fiber structure and could then improve feed utilization for ruminant. In an earlier study, Suntara and Cherdthong ${ }^{13}$ suggested that, when compared to S. cerevisiae, the ensiled RS with P. kudriavzevii KKU20 and $C$. tropicalis KKU20 had the greater ability to increase cumulative gas production and improve in vitro degradability. However, applying potential yeast in RS fed to dairy cattle has not yet been reported. It was expected that the $P$. kudriavzevii KKU20 and $C$. tropicalis KKU20 from the rumen may support the feed utilization and performance production of tropical dairy cattle.

This research aimed to determine the effects of newly isolated ruminal Crabtree-negative yeast ensiled RS on feed intake, ruminal fermentation, milk production, and milk composition in tropical crossbred lactating Holstein cows.

\section{Results}

\section{Chemical composition of feeds}

The ensiled RS with different yeast species contained CP at 58.9 to $71.2 \mathrm{~g} / \mathrm{kg} \mathrm{DM}$ and 8.4 to $8.5 \mathrm{MJ} / \mathrm{kg}$ DM of ME, while the concentrate diet contained CP at $178.0 \mathrm{~g} / \mathrm{kg} \mathrm{DM}$ and $12.3 \mathrm{MJ} / \mathrm{kg}$ DM of ME. The NDF content in ensiled RS with P. kudriavzevii KKU20 and $C$. tropicalis KKU20 were lower than in $S$. cerevisiae at $12.7 \%$ and $12.1 \%$, respectively (Table 1 ). Fermentation quality of ensiled RS such as pH were ranged from 4.19 to 4.30 , while lactic acid, $\mathrm{C}_{2}, \mathrm{C}_{4}$, and $\mathrm{NH}_{3}-\mathrm{N}$ were ranged from 19.8 to 21.9, 5.1 to 5.4, 0.81 to 0.82 , and 1.8 to $2.0 \mathrm{~g} / \mathrm{kg} \mathrm{DM}$, respectively. 
Table 1

Dietary ingredients and chemical composition of different yeast species in ensiled rice straw and concentrate diet. Premix = Vitamins and minerals; A: 10,000,000 IU; Vitamin E: 70,000 IU; Vitamin D: 1,600,000 IU; Fe: 50 g; Zn: 40 g; Mn: 40 g; Co: 0.1 g; Cu: 10 g; Se: 0.1 g; I: 0.5 g. Hemicellulose = NDF-ADF Cellulose $=$ ADF-lignin Metabolizable energy calculated according to the equation described by Robinson et al. (2004).

\begin{tabular}{|c|c|c|c|c|}
\hline \multirow[t]{3}{*}{ Item } & \multicolumn{3}{|c|}{ Ensiled rice straw (g/kg fresh matter) } & \multirow{3}{*}{$\begin{array}{l}\text { Concentrate diet } \\
(\mathrm{g} / \mathrm{kg} \mathrm{DM})\end{array}$} \\
\hline & \multirow[t]{2}{*}{ S. cerevisiae } & P. kudriavzevii & C. tropicalis & \\
\hline & & KKU20 & KKU20 & \\
\hline \multicolumn{5}{|l|}{ Ingredients } \\
\hline Cassava ship & - & - & - & 470.1 \\
\hline Corn & - & - & - & 77.0 \\
\hline Palm kernel meal & - & - & - & 100.0 \\
\hline Rice bran & - & - & - & 99.0 \\
\hline Soybean meal & - & - & - & 200.0 \\
\hline Molasses & 500.0 & 500.0 & 500.0 & 33.0 \\
\hline Premix & - & - & - & 0.3 \\
\hline Di-calcium phosphate & - & - & - & 0.1 \\
\hline Urea & 20.0 & 20.0 & 20.0 & 15.0 \\
\hline Salt & - & - & - & 5.5 \\
\hline \multicolumn{5}{|c|}{ Chemical composition (g/kg DM) } \\
\hline Dry matter (g/kg as fed) & 279.3 & 275.7 & 278.7 & 903.4 \\
\hline Organic matter & 871.4 & 879.0 & 874.1 & 941.3 \\
\hline Ether extract & 7.8 & 8.2 & 7.4 & 46.2 \\
\hline Crude protein & 60.8 & 58.9 & 71.2 & 178.0 \\
\hline Neutral detergent fiber & 715.3 & 624.6 & 629.3 & 391.1 \\
\hline Acid detergent fiber & 452.2 & 390.8 & 396.6 & 135.1 \\
\hline Acid detergent lignin & 64.6 & 60.6 & 61.6 & 30.5 \\
\hline Hemicelluose & 263.1 & 233.9 & 232.8 & 256.0 \\
\hline Cellulose & 387.6 & 330.1 & 335.0 & 104.6 \\
\hline \multicolumn{5}{|c|}{ Energy content (MJ/kg DM) } \\
\hline Gross energy & 15.1 & 15.1 & 15.0 & 16.1 \\
\hline
\end{tabular}




\begin{tabular}{|lllll|}
\hline Item & \multicolumn{2}{l}{ Ensiled rice straw (g/kg fresh matter) } & Concentrate diet \\
\cline { 2 - 4 } & S. cerevisiae & $\begin{array}{l}\text { P. kudriavzevii } \\
\text { KKU20 }\end{array}$ & $\begin{array}{l}\text { C. tropicalis } \\
\text { KKU20 }\end{array}$ & (g/kg DM) \\
\hline Metabolizable energy & 8.4 & 8.4 & 8.5 & 12.3 \\
\hline Fermentation quality & & & & \\
\hline pH & 4.20 & 4.30 & 4.21 & - \\
\hline Lactic acid (g/kg DM) & 19.8 & 21.9 & 22.1 & - \\
\hline Acetic acid (g/kg DM) & 5.4 & 5.4 & 5.1 & - \\
\hline Butyric acid (g/kg DM) & 0.82 & 0.82 & 0.81 & - \\
\hline Ammonia-N (g/kg DM) & 2.0 & 2.0 & 1.8 & - \\
\hline
\end{tabular}

\section{Feed intake, nutrient intake, and nutrient apparent digestibility}

The impacts of different yeast species ensiled RS on the effectiveness of feed utilization in dairy cattle is illustrated in Table 2.. The yeast species did not change the RS intake, concentrate diet, and total intake $(P>0.05)$. Total intake ranged from 111.7 to $121.1 \mathrm{~g} / \mathrm{kg} \mathrm{BW}^{0.75}$. OM and CP intake were 8.9 to $9.6 \mathrm{~kg} / \mathrm{day}$ and 1.3 to $1.4 \mathrm{~kg} /$ day, respectively, which was not altered among treatments $(P>0.05)$. Crabtree-negative yeast ( $P$. kudriavzevii KKU20 and $C$. tropicalis KKU20) increased the apparent digestibility of DM by about $6.9 \%$ when compare with Crabtree-positive yeast (S. cerevisiae). However, the data achieved in this study showed that apparent digestibility of OM (OMD), CP (CPD), NDF (NDFD), and ADF (ADFD) were not altered among yeast species and ranged from 762.1 to $791.5,752.0$ to $791.5,601.5$ to 641.3 , and 492.8 to $525.4 \mathrm{~g} / \mathrm{kg}$, respectively. Furthermore, the total digestible nutrients were the same among yeast species and ranged from 734.8 to $767.7 \mathrm{~g} / \mathrm{kg}(P>0.05)$. 
Table 2

Effect of different yeast species in ensiled rice straw on dry mater intake (DMI), nutrient intake and digestibility in tropical crossbred lactating dairy cows. ${ }^{a}, b$ Means in the same row with different superscript letters differ $(\mathrm{P}<0.01, \mathrm{P}<0.05)$. S. cerevisiae $=$ Saccharomyce cerevisiae, $P$. kudriavzevii $=$ Pichia kudriavzevii, C. tropicalis = Candida tropicalis.

\begin{tabular}{|c|c|c|c|c|c|}
\hline Items & S. cerevisiae & $\begin{array}{l}\text { P. kudriavzevii } \\
\text { KKU20 }\end{array}$ & $\begin{array}{l}\text { C. tropicalis } \\
\text { KKU20 }\end{array}$ & SEM & P-value \\
\hline \multicolumn{6}{|l|}{ Dry matter intake } \\
\hline \multicolumn{6}{|l|}{ Rice straw silage } \\
\hline $\mathrm{kg} / \mathrm{d}$ & 3.7 & 3.8 & 3.1 & 0.41 & 0.17 \\
\hline$\% \mathrm{BW}$ & 1.0 & 1.0 & 0.8 & 0.10 & 0.11 \\
\hline $\mathrm{g} / \mathrm{kgBW}^{0.75}$ & 43.4 & 45.0 & 36.5 & 4.54 & 0.11 \\
\hline \multicolumn{6}{|l|}{ Concentrate diet } \\
\hline $\mathrm{kg} / \mathrm{d}$ & 5.9 & 6.3 & 6.2 & 0.19 & 0.11 \\
\hline$\%$ BW & 1.7 & 1.8 & 1.7 & 0.06 & 0.27 \\
\hline $\mathrm{g} / \mathrm{kgBW}^{0.75}$ & 72.3 & 76.1 & 75.2 & 2.53 & 0.21 \\
\hline \multicolumn{6}{|l|}{ Total intake } \\
\hline $\mathrm{kg} / \mathrm{d}$ & 9.6 & 10.1 & 9.3 & 0.55 & 0.25 \\
\hline$\%$ BW & 2.7 & 2.8 & 2.6 & 0.15 & 0.27 \\
\hline $\mathrm{g} / \mathrm{kgBW}^{0.75}$ & 115.7 & 121.1 & 111.7 & 4.54 & 0.11 \\
\hline \multicolumn{6}{|l|}{ Nutrient intake, $\mathrm{kg} / \mathrm{d}$} \\
\hline Organic matter & 9.1 & 9.6 & 8.9 & 0.49 & 0.24 \\
\hline Ether extract & 0.3 & 0.3 & 0.3 & 0.01 & 0.11 \\
\hline Crude protein & 1.3 & 1.4 & 1.4 & 0.05 & 0.35 \\
\hline Neutral detergent fiber & 5.1 & 4.9 & 4.5 & 0.32 & 0.13 \\
\hline Acid detergent fiber & 2.5 & 2.4 & 2.1 & 0.18 & 0.08 \\
\hline \multicolumn{6}{|c|}{ Apparent digestibility, g/kg } \\
\hline Dry matter & $701.4^{\mathrm{b}}$ & $746.5^{\mathrm{a}}$ & $753.1^{\mathrm{a}}$ & 15.3 & $P<0.05$ \\
\hline Organic matter & 762.1 & 763.4 & 791.5 & 24.4 & 0.30 \\
\hline Crude protein & 752.0 & 754.8 & 786.4 & 29.6 & 0.34 \\
\hline
\end{tabular}




\begin{tabular}{|llllll|}
\hline Items & S. cerevisiae & $\begin{array}{l}\text { P. kudriavzevii } \\
\text { KKU20 }\end{array}$ & $\begin{array}{l}\text { C. tropicalis } \\
\text { KKU20 }\end{array}$ & SEM & P-value \\
\hline Neutral detergent fiber & 601.5 & 658.8 & 641.3 & 28.1 & 0.17 \\
\hline Acid detergent fiber & 492.8 & 525.4 & 510.9 & 21.1 & 0.34 \\
\hline Total digestible nutrient & 734.8 & 739.0 & 767.7 & 23.1 & 0.23 \\
\hline
\end{tabular}

\section{Effect on rumen $\mathrm{pH}, \mathrm{NH}_{3}-\mathrm{N}$, blood metabolites and microbial communities}

Table 3 illustrates the influence of ensiled RS with various yeast species fed to crossbred lactating dairy cows on ruminal $\mathrm{pH}, \mathrm{NH}_{3}-\mathrm{N}, \mathrm{BUN}$, and microbial communities. Rumen $\mathrm{pH}$ was not changed among yeast species, and the $\mathrm{pH}$ values were 6.4 to $6.8(\mathrm{P}>0.05)$. Ruminal $\mathrm{NH}_{3}-\mathrm{N}$ and $\mathrm{BUN}$ ranged from 16.5 to $22.1 \mathrm{mg} / \mathrm{dL}$ and 13.3 to $17.3 \mathrm{mg} / \mathrm{dL}$, respectively $(P>0.05)$. The bacterial populations at both 0 hours and 4 hours after feeding and the mean value were highest $(P<0.05)$ with ensiled RS with $C$. tropicalis KKU20 by $9.9,12.5$ and 11.2 Log10 cell/ml, respectively. However, the fungal zoospore and protozoa populations were not affected by any treatments $(P>0.05)$. 
Table 3

Effect of different yeast species in rice straw ensiled on ruminal $\mathrm{pH}, \mathrm{NH}_{3}-\mathrm{N}$ concentration, blood urea-nitrogen concentration, and microbial communities in crossbred lactating dairy cows. ${ }^{a}$ b Means in the same row with different superscript letters differ $(\mathrm{P}<0.01, \mathrm{P}<0.05)$. S. cerevisiae= Saccharomyce cerevisiae, P. kudriavzevii = Pichia kudriavzevii, C. tropicalis = Candida tropicalis.

\begin{tabular}{|c|c|c|c|c|c|}
\hline Items & S. cerevisiae & $\begin{array}{l}\text { P. kudriavzevii } \\
\text { KKU20 }\end{array}$ & $\begin{array}{l}\text { C. tropicalis } \\
\text { KKU20 }\end{array}$ & SEM & P-value \\
\hline \multicolumn{6}{|l|}{ Ruminal pH } \\
\hline 0 hours-after feeding & 6.8 & 6.8 & 6.8 & 0.11 & 0.71 \\
\hline 4 hours-after feeding & 6.4 & 6.5 & 6.4 & 0.19 & 0.98 \\
\hline mean & 6.6 & 6.6 & 6.7 & 0.14 & 0.86 \\
\hline \multicolumn{6}{|l|}{ Ruminal $\mathrm{NH}_{3}-\mathrm{N}, \mathrm{mg} / \mathrm{dL}$} \\
\hline 0 hours -after feeding & 17.7 & 16.5 & 16.7 & 1.32 & 0.52 \\
\hline 4 hours -after feeding & 20.7 & 18.9 & 22.1 & 1.40 & 0.06 \\
\hline mean & 19.2 & 17.7 & 19.4 & 1.11 & 0.18 \\
\hline \multicolumn{6}{|l|}{$\mathrm{BUN}, \mathrm{mg} / \mathrm{dL}$} \\
\hline 0 hours -after feeding & 13.8 & 13.5 & 13.3 & 2.45 & 0.97 \\
\hline 4 hours -after feeding & 15.8 & 16.0 & 17.3 & 1.13 & 0.26 \\
\hline mean & 14.8 & 14.8 & 15.3 & 1.45 & 0.87 \\
\hline \multicolumn{6}{|c|}{ Rumen microbes, cells/ml } \\
\hline \multicolumn{6}{|l|}{ Bacteria, Log10 cell/ml } \\
\hline 0 hours -after feeding & $9.2^{b}$ & $9.4^{\mathrm{ab}}$ & $9.9^{a}$ & 0.28 & $p<0.05$ \\
\hline 4 hours -after feeding & $11.9^{b}$ & $12.2^{\mathrm{a}}$ & $12.5^{\mathrm{a}}$ & 0.22 & $p<0.05$ \\
\hline mean & $10.5^{\mathrm{b}}$ & $10.8^{\mathrm{ab}}$ & $11.2^{\mathrm{a}}$ & 0.19 & $p<0.01$ \\
\hline \multicolumn{6}{|l|}{ Fungi zoospore, } \\
\hline \multicolumn{6}{|l|}{ Log10 cell/ml } \\
\hline 0 hours -after feeding & 7.8 & 8.1 & 8.1 & 0.29 & 0.31 \\
\hline 4 hours -after feeding & 6.9 & 6.9 & 6.9 & 0.33 & 0.43 \\
\hline mean & 5.9 & 5.7 & 5.6 & 0.24 & 0.27 \\
\hline
\end{tabular}




\begin{tabular}{|llllll|}
\hline Items & S. cerevisiae & $\begin{array}{l}\text { P. kudriavzevii } \\
\text { KKU20 }\end{array}$ & $\begin{array}{l}\text { C. tropicalis } \\
\text { KKU20 }\end{array}$ & SEM & P-value \\
\hline 0 hours -after feeding & 4.3 & 4.6 & 4.6 & 0.30 & 0.38 \\
\hline 4 hours -after feeding & 5.9 & 6.2 & 6.2 & 0.27 & 0.39 \\
\hline mean & 5.1 & 5.4 & 5.3 & 0.17 & 1.00 \\
\hline
\end{tabular}

\section{Effect on ruminal volatile fatty acid}

The total VFA, acetic acid $\left(\mathrm{C}_{2}\right)$, propionic acid $\left(\mathrm{C}_{3}\right)$, butyric acid $\left(\mathrm{C}_{4}\right)$ proportions, and acetic acid to propionic acid ratio are illustrated in Table 4. Ensiled RS with $P$. kudriavzevii KKU20 and $C$. tropicalis KKU20 were significantly increased with a total VFAs at 0 hours ( 5.15 and $5.06 \%$, respectively), and 4 hours (5.07 and $8.83 \%$, respectively) after feeding $(P<0.05)$ when compared with $S$. cerevisiae, whereas yeasts ensiled RS had no effect on the VFAs' profile $(P>0.05)$. The mean value of $C_{2}, C_{3}$, and $C_{4}$ were $67.4,22.3$, and $10.3 \mathrm{~mol} / 100 \mathrm{~mol}$, respectively. 
Table 4

Effect of different yeast species in rice straw ensiled on concentrations of total volatile fatty acid

(VFAs) and their profiles in crossbred lactating dairy cows. ${ }^{a}, \mathrm{~b}$ Means in the same row with different superscript letters differ $(\mathrm{P}<0.01, \mathrm{P}<0.05)$. S. cerevisiae= Saccharomyce cerevisiae, $P$. kudriavzevii = Pichia kudriavzevii, C. tropicalis = Candida tropicalis.

\begin{tabular}{|c|c|c|c|c|c|}
\hline \multirow[t]{2}{*}{ Items } & \multirow[t]{2}{*}{ S. cerevisiae } & \multirow{2}{*}{$\begin{array}{l}\text { P. kudriavzevii } \\
\text { KKU20 }\end{array}$} & \multirow{2}{*}{$\begin{array}{l}\text { C. tropicalis } \\
\text { KKU20 }\end{array}$} & \multirow[t]{2}{*}{ SEM } & \multirow[t]{2}{*}{$P$-value } \\
\hline & & & & & \\
\hline \multicolumn{6}{|l|}{ Total VFA, mmol/L } \\
\hline 0 hours -after feeding & $106.7^{b}$ & $112.2^{\mathrm{a}}$ & $112.1^{\mathrm{a}}$ & 2.38 & $p<0.05$ \\
\hline 4 hours -after feeding & $122.3^{b}$ & $128.5^{\mathrm{ab}}$ & $133.1^{\mathrm{a}}$ & 4.07 & $p<0.05$ \\
\hline mean & $114.5^{\mathrm{b}}$ & $120.4^{\mathrm{a}}$ & $122.6^{a}$ & 2.11 & $p<0.01$ \\
\hline \multicolumn{6}{|c|}{$\begin{array}{l}\text { Volatile fatty acid profiles, } \\
\mathrm{mol} / 100 \mathrm{~mol}\end{array}$} \\
\hline \multicolumn{6}{|l|}{ Acetic acid } \\
\hline 0 hours -after feeding & 64.9 & 65.8 & 65.9 & 0.86 & 0.35 \\
\hline 4 hours -after feeding & 68.4 & 68.8 & 70.6 & 1.45 & 0.20 \\
\hline mean & 66.7 & 67.3 & 68.3 & 0.97 & 0.19 \\
\hline \multicolumn{6}{|l|}{ Propionic acid } \\
\hline 0 hours -after feeding & 21.0 & 21.9 & 20.7 & 1.03 & 0.36 \\
\hline 4 hours -after feeding & 22.6 & 24.1 & 23.2 & 1.13 & 0.32 \\
\hline mean & 21.8 & 23.0 & 21.9 & 0.93 & 0.27 \\
\hline \multicolumn{6}{|l|}{ Butyric acid } \\
\hline 0 hours -after feeding & 14.0 & 12.2 & 13.3 & 1.11 & 0.20 \\
\hline 4 hours -after feeding & 8.9 & 7.1 & 6.2 & 1.53 & 0.14 \\
\hline mean & 11.5 & 9.7 & 9.8 & 0.72 & 0.02 \\
\hline \multicolumn{6}{|c|}{ Acetic:Propionic acid ratio } \\
\hline 0 hours -after feeding & 3.1 & 3.0 & 3.2 & 0.17 & 0.48 \\
\hline 4 hours -after feeding & 3.1 & 2.9 & 3.1 & 0.18 & 0.34 \\
\hline mean & 3.1 & 2.9 & 3.1 & 0.17 & 0.36 \\
\hline
\end{tabular}




\section{Effect on milk production, milk composition, and feed efficiency}

The effects of ensiled RS with various yeast species on milk production, composition of milk, and feed efficiency in dairy cows are shown in Table 5 . The yeast strains' effects were not observed $(P>0.05)$ on actual milk yields ( 8.5 to $8.8 \mathrm{~kg} / \mathrm{h} / \mathrm{d}$ ), $4.0 \%$ FCM $(7.6$ to $8.3 \mathrm{~kg} / \mathrm{h} / \mathrm{d})$, and ECM $(7.7$ to $8.3 \mathrm{~kg} / \mathrm{h} / \mathrm{d})$. The treatments did not alter the milk composition $(P>0.05)$; except for when the protein in the milk was highest in the $C$. tropicalis KKU20 fed group at $35.6 \mathrm{~g} / \mathrm{kg}(P<0.01)$. Feed efficiency did not changed for any diets $(P>0.05)$. 
Table 5

Effect of different yeast species in rice straw ensiled on milk yield, milk composition, feed efficiency and economic efficiency in crossbred lactating dairy cows. ${ }^{a}$ b Means in the same row with different superscript letters differ $(\mathrm{P}<0.01, \mathrm{P}<0.05)$. S. cerevisiae $=$ Saccharomyce cerevisiae,

P. kudriavzevii = Pichia kudriavzevii, . . tropicalis = Candida tropicalis. FCM = fat corrected milk ( calculated from $0.432(\mathrm{~kg}$ of milk/d) $+16.23(\mathrm{~kg}$ of fat). ECM = energy-corrected milk =

$7.20 \times$ protein $(\mathrm{kg} / \mathrm{d})+12.95 \times f a t(\mathrm{~kg} / \mathrm{d})+0.327 \times$ milk $(\mathrm{kg} / \mathrm{d})$. $\mathrm{DMI}=$ dry matter intake. $\mathrm{DCP}=$ digestible crude protein.

\begin{tabular}{|c|c|c|c|c|c|}
\hline Items & S. cerevisiae & $\begin{array}{l}\text { P. kudriavzevii } \\
\text { KKU20 }\end{array}$ & $\begin{array}{l}\text { C. tropicalis } \\
\text { KKU20 }\end{array}$ & SEM & P-value \\
\hline Actual milk yield, kg/h/day & 8.5 & 8.8 & 8.6 & 0.47 & 0.09 \\
\hline $4.0 \% \mathrm{FCM}, \mathrm{kg} / \mathrm{h} /$ day & 7.8 & 7.6 & 8.3 & 0.39 & 0.11 \\
\hline $\mathrm{ECM}, \mathrm{kg} / \mathrm{h} / \mathrm{d}$ & 7.8 & 7.7 & 8.3 & 0.30 & 0.07 \\
\hline Protein, $\mathrm{g} / \mathrm{kg}$ & $34.5^{\mathrm{b}}$ & $34.1^{\mathrm{b}}$ & $35.6^{\mathrm{a}}$ & 0.02 & $p<0.05$ \\
\hline Protein, g/d & 292.7 & 302.2 & 303.4 & 12.4 & 0.54 \\
\hline Fat, $\mathrm{g} / \mathrm{kg}$ & 33.9 & 32.0 & 37.9 & 3.89 & 0.23 \\
\hline Fat, g/d & 288.8 & 269.7 & 325.6 & 28.9 & 0.11 \\
\hline Lactose, $\mathrm{g} / \mathrm{kg}$ & 44.7 & 45.1 & 44.5 & 0.05 & 0.44 \\
\hline Lactose, $\mathrm{g} / \mathrm{d}$ & 382.6 & 399.3 & 382.5 & 12.3 & 0.22 \\
\hline Solids-not-fat, g/kg & 87.2 & 86.9 & 87.9 & 0.71 & 0.27 \\
\hline Total solids, g/kg & 122.7 & 121.2 & 126.9 & 2.91 & 0.09 \\
\hline Somatic cell count, $\times 10^{5}$ & 5.3 & 4.0 & 6.6 & 1.25 & 0.10 \\
\hline Milk urea nitrogen, $\mathrm{mg} / \mathrm{dL}$ & 12.9 & 13.1 & 14.7 & 0.85 & 0.06 \\
\hline \multicolumn{6}{|l|}{ Feed efficiency } \\
\hline Milk / DMI & 0.90 & 0.87 & 0.92 & 0.05 & 0.62 \\
\hline ECM / DMI & 0.82 & 0.76 & 0.89 & 0.06 & 0.07 \\
\hline DCP / Milk & 93.4 & 91.1 & 97.3 & 4.02 & 0.22 \\
\hline
\end{tabular}

\section{Discussions}

From NRC ${ }^{36}, \mathrm{CP}$ and ME requirement of our animal (BW $364 \mathrm{~kg}$, milk yield $8.6 \mathrm{~kg} / \mathrm{d}$ ) increased by about $1,190 \mathrm{~g} / \mathrm{d}$ and $60.9 \mathrm{MJ} / \mathrm{d}$, respectively. Therefore, the nutrient composition in feed, especially CP (provide 1,300-1,400 g CP/d) and ME (provide 79.05-84.14 MJ/d) values, were sufficient in our study for supporting dairy cows' performance. Furthermore, ensiled RS with $P$. kudriavzevii KKU20 and $C$. tropicalis KKU20 (Crabtree-negative yeast) were established as having a low fiber content when compared with 
adding S. cerevisiae (Crabtree-positive yeast). The low fiber content can be clarified by the yeast's ability to release cellulase enzymes and digest fiber during the fermentation process. Suntara and Cherdthong ${ }^{8}$ confirmed that $C$. tropicalis KKU20 and $P$. kudriavzevii KKU20 were more capable to releasing cellulase enzymes than $S$. cerevisiae by about 0.7 to 6.8 times, respectively. Moreover, the experiment on in vitro gas production of ensiled RS at 14 days with the $P$. kudriavzevii KKU20 could decrease the NDF content by about $6.7 \%$ when compared with $S$. cerevisiae ${ }^{15}$. Ilmén et al. ${ }^{37}$ discovered yeast isolated from a plant named $C$. konsanensis species could excrete cellulase enzymes and digests fiber, and it is a new yeast strain that had not been reported previously. Similar with our study, $C$. tropicalis KKU20 and P. kudriavzevii KKU20 are great potential yeasts to improve feedstuffs and this study is the first report in ruminant nutrition feed research.

The fermentation quality of ensiled RS with different yeast species indicated that the silage was well preserved. The ensiled RS still maintained appropriate $\mathrm{pH}$, high lactic acid content, and a low $\mathrm{NH}_{3}-\mathrm{N}$ level. Acceptable silage was defined by the $\mathrm{pH}$ value and the composition of their fermentation products ${ }^{38}$. The $\mathrm{pH}$ is the main indicator for evaluating silage quality and our study showed ensiled RS still has a satisfactory score of about 4.1 to $4.3^{39}$. In addition, $\mathrm{pH}$ is highly related with lactic acid content, which in this study showed a consistent range of about 19.8-22.1 g/ $\mathrm{kg} \mathrm{DM}$. Lactic acid content in silage should range between 21 to $25 \mathrm{~g} / \mathrm{kg}$ DM to be considered of high quality, according to Flieg's score ${ }^{40}$; therefore, it is close to the high quality of silage. In addition, our result showed lactic acid content similar to an earlier study by Suntara et al. ${ }^{15}$ who revealed that about 20.53 to $26.14 \mathrm{~g} / \mathrm{kg} \mathrm{DM}$ of lactic acid was produced when ensiled RS with $C$. tropicalis KKU20 and P. kudriavzevii KKU20 at 14 day. $\mathrm{NH}_{3}-\mathrm{N}$ concentration in ensiled RS within the range of 1.80 to $2.00 \mathrm{~g} / \mathrm{kg} \mathrm{DM}$ indicated the normal standards for estimating silage. These results are similar to those of Li et al. ${ }^{41}$, who collected information on various types of RS parameters and concluded that RS silage has a $\mathrm{NH}_{3}-\mathrm{N}$ concentration of approximately 1.61 to $2.36 \mathrm{~g} / \mathrm{kg}$ DM. Other parameter such as $\mathrm{C}_{2}$ show great value for preserved silage within range 20 to $25 \mathrm{~g} / \mathrm{kg} \mathrm{DM}^{39}$. Moreover, after the fermentation process, the moisture content should range from 650 to $750 \mathrm{~g} / \mathrm{kg}$ to be optimum ${ }^{16}$, which in our study showed an average of $722.1 \mathrm{~g} / \mathrm{kg}$. Therefore, our study proposes that the nutrients in ensiled RS are still well preserved.

Crabtree-negative or - positive yeast has no effect on the dry matter intake (DMI). Our results showed that the DMI (range from 2.6 to $2.8 \% \mathrm{BW}$ ) was similar to previous experiments, which is that feeding separate ensiled RS with a concentrate diet to dairy cows creates a DMI range from 2.5 to $3.2 \% \mathrm{BW}{ }^{42,43}$. Generally, the amount of RS that an animal intakes daily is limited to around $2.0 \%$ BW or less BW ${ }^{44}$. Because RS is rich in polysaccharides and has a high lignin and silica content, and thus it limits the voluntary intake 45 . However, Aquino et al. ${ }^{46}$ reported that the amount of RS that ruminants can consume can be as high as $1.2 \% \mathrm{BW}$, which is similar with our result of $0.8-1.0 \% \mathrm{BW}$. The intake of $\mathrm{OM}, \mathrm{EE}, \mathrm{NDF}$, and ADF was similar with previous studies of lactating crossbred dairy cows ${ }^{47,48}$. The $\mathrm{CP}$ intake (CPI) in this study was also similar with Wanapat, et al. ${ }^{43}$, which used lactating crossbred dairy cows $(50 \%$ Holstein Frisian $\times 50 \%$ Thai native cows) and BW around $365.5 \mathrm{~kg}$, and the CPI was about 1.0 to $1.2 \mathrm{~kg} / \mathrm{d}$. Typically, the CP 
found in tropical forage plants is often relatively low ${ }^{49}$. Especially in RS (3\%CP) when using a roughage source it can have an effect on the animal's yield adequacy ${ }^{50}$. However, our study showed that ensiled RS with yeast could support protein from yeast to low quality roughage as RS, and the enhanced intake of protein were high enough to meet the requirement of tropical lactation dairy cows.

The dry matter digestibility (DMD) was increased when ensiled RS with Crabtree negative yeast was offered to animals. This strain is outstanding in terms of high proliferation ability and its high yield of cellulase enzymes ${ }^{15}$. The improved digestion may be due to the potential of how rumen microflora are promoted for better digestibility. Yeast is an important biological responder in the rumen fermentation, live yeast cells improve microorganisms in rumen ${ }^{51}$ and stabilizes $\mathrm{pH}$ in the rumen ${ }^{52}$. Habeeb ${ }^{53}$ stated that yeast could provide rumen with biological stimulants, which is necessary for microorganisms' growth in the rumen. Therefore, yeast contributes to establishing microbiota ${ }^{54}$ and is why the digestibility was apparently enhanced. This is consistence with Wang et al. ${ }^{6}$, who found that Crabtree-negative yeast as $C$. tropicalis could increase digestion in the in vitro technique and that it generated $3.03 \%$ more gas production than did S. cerevisiae.

However, Crabtree-negative yeast did not change the apparent digestibility of $O M, C P, N D F$, and ADF. The digestibility of NDF and ADF are similar among Cabtree-negative and positive yeast (601.50 vs $650.05 \mathrm{~g} / \mathrm{kg}$ DM and 492.8 vs $518.15 \mathrm{~g} / \mathrm{kg} \mathrm{DM}$, respectively). Noticeable changes occurred after the silage process was complete, but when the animal intakes the feed, its digestion was not altered. The reason for this is still not clear, but it is possible that yeast does not react directly on RS. Rather, digestion in the rumen occurred by the cooperation of microbes' synergy until the resulting values were not statistically different. This is similar with an experiment by Suntara et al. ${ }^{15}$, who compared the effect of Crabtree-negative and -positive yeast on ensiled RS on the in vitro gas and confirmed that in the rumen, there was no difference among yeast species in the digestibility of NDF and ADF (705.2 vs 703.6 and 464.8 vs $464.4 \mathrm{~g} / \mathrm{kg} \mathrm{DM})$.

Ensiled RS with the P. kudriavzevii KKU20 and C. tropicalis KKU20 (Crabtree-negative yeast) could increase bacterial populations when compared to S. cerevisiae (Crabtree-positive yeast) by about $4.76 \%$. The ruminal bacterial populations depend on sufficient nutrients or stimulants supply ${ }^{53}$. Yeast is a great supply to stimulate bacteria because it is enriched in essential substances ${ }^{55}$. Previous studies have confirmed that yeast could supply essential amino acids, vitamins, and minerals to increase the ruminal bacteria more than without yeast ${ }^{2,56}$. The key explanation is that under aerobic conditions, Crabtreenegative yeast may proliferate more than Crabtree-positive yeast since the enzyme mechanism functions differently ${ }^{9,57}$. Suntara and Cherdthong ${ }^{8}$ found that at $72 \mathrm{~h}$ of incubation time, P. kudriavzevii KKU20, $C$. tropicalis KKU20, and S. cerevisiae had growth by about 10.02, 9.6, and 8.87 Log cells/ml, respectively. The high amount of Crabtree-negative yeast creates a greater supply of essential nutrients to the rumen bacteria ${ }^{15}$, thus the amount of rumen bacteria is increased in response to the Crabtree-negative yeast. 
The ensiled RS with Crabtree-negative yeast has more effect on the total VFAs than with Crabtree-positive yeast by about $6.1 \%$ at the mean value. The high production of total VFAs in rumen fluids is related to the amount of ruminal bacteria ${ }^{58}$. The great bacterial population could enhance carbohydrate digestion and then the animal obtains the greater VFAs ${ }^{59}$. This is similar to Castillo-González et al. ${ }^{60}$, who stated that the expansion of rumen microorganisms could increase the quantity of rumen VFAs. Certainly, a high bacterial population in our experiment was related with the Crabtree-negative yeast's effect. Nonetheless, the direct influence of the Crabtree-negative yeast on rumen bacterial populations was unclear and this hypothesis required further research to be conducted. However, expanding the Crabtree-negative yeast population (during fermentation process) may be more effective than expanding that of the Crabtreepositive yeast (S. cerevisiae). This suggests that animals have a greater chance of obtaining stimulants for activate rumen bacteria. In agreement with our results, Wang et al. ${ }^{6}$ compared the effect between Crabtree-negative yeast (C. tropicalis) and Crabtree-positive yeast (S. cerevisiae) for in vitro gas technique and found that the inclusion of $0.25 \times 10^{7}$ of Crabtree-negative yeast could enhanced the total VFAs by 7.7\%. Moreover, Suntara et al. ${ }^{15}$ reported that Crabtree-negative yeast ( $P$. kudriavzevii KKU20) increased the total VFAs by $2.3 \%$ for in vitro gas study more than Crabtree-positive yeast.

The milk yield and milk composition of ensiled RS with Crabtree-negative yeast did not have any impact. Our study showed that the actual milk yields are about 8.5 to $8.8 \mathrm{~kg} / \mathrm{h} / \mathrm{d}$, which are slightly lower than previous trials using early to mid-lactation cows $\left(12.6 \mathrm{~kg} / \mathrm{h} / \mathrm{d}\right.$ according to Supapong and Cherdthong ${ }^{61}$; $11.1 \mathrm{~kg} / \mathrm{h} / \mathrm{d}$ according to Wanapat et al. $\left.{ }^{43}\right)$. To produce milk, cows must calve and split its lactation cycle into four phases (early, mid, late lactation and dry period) ${ }^{62}$. The milk yield response was greater in the early lactation, and in the mid-lactation period, the milk yield begins to decline from its peak ${ }^{63}$. Therefore, the lower actual milk yields in this study may be because dairy cows were in mid to late lactation (DIM 165.5 to 186.5). Our study indicated that daily protein yields in milk of the $C$. tropicalis KKU20 group was highest at $35.6 \mathrm{~g} / \mathrm{kg}$ and lowest when applied with $S$. cerevisiae and $P$. kudriavzevii KKU20 in ensiled RS at 34.5 and $34.1 \mathrm{~g} / \mathrm{kg}$, respectively. Milk protein is associated with the feed degradation energy supply as VFAs and microbial protein (MCP) synthesis ${ }^{64}$. High amounts of microorganisms in rumen could affect the MCP synthesis. This will be the supply protein and amino acids $(A A)$ in the small intestine and could enhance the milk protein yields ${ }^{65}$. Our result clearly demonstrated that $C$. tropicalis KKU20 was unique in the highest bacterial population ( 11.2 Log10 cell / $\mathrm{ml}$ ), which is why the increase in milk protein yields occurred. Furthermore, there were no differences in milk proteins between $S$. cerevisiae and $P$. kudriavzevii KKU20. This suggests that the influence of Crabtree-negative yeast may play different roles in terms of milk quality. This thought is support by Intanoo et al. ${ }^{66}$, who compared different yeast strains that were in the same group of Crabtree-negative, and found that $P$. kudriavzevii KKU20 decreased daily protein yields in milk by $14.9 \%$ when compared with Kluyveromyces marxianus in crossbred lactating cows. This yeast species could provide high biomass, which possibly supplies more amino acid sources for milk protein synthesis. This is similar to Wardrop et al. ${ }^{11}$ who stated that $K$. marxianus has an outstanding ability to provide high biomass when compared with other strain. The explanation is limited in regard to $P$. kudriavzevii's impact on daily protein yields in 
milk. A few studies have focused on applying non-S. cerevisiae to dairy cows and further research about the influence of each strain is required.

Based on this study, we conclude that Crabtree-negative yeast-treated RS, especially C. tropicalis KKU20, could enhance the RS's nutrition value through increasing DMD, the ruminal bacterial population, and total VFAs. In addition, $C$. tropicalis KKU20 could increase the milk protein when compared with other groups. However, there are certain drawbacks associated with the high-producing lactating cows influenced by $C$. tropicalis KKU20 treated RS, which requires further investigation.

\section{Methods}

The animals participating in this study have been certified by the Khon Kaen University Animal Ethics Committee (Record No. IACUC-KKU 38/62), based on the Ethics of Animal Experimentation of the National Research Council of Thailand. In addition, we confirmed that all methods were performed in accordance with the relevant guidelines and regulations.

\section{Animals and experimental design}

This study used 6 multiparous crossbreds between Holstein Frisian $\times$ Zebu dairy cows in their midlactation period ( $165.5 \pm 44.0$ of day-in-milk) with an initial body weight of $363.9 \pm 55.80 \mathrm{~kg}$ (average milk yield $8.58 \mathrm{~kg} / \mathrm{d}$ ) and a mean age of 5 years. The milk yield reported was slightly higher than the previous studies, which Holstein Frisian $\times$ Zebu cow's milk yields were $2,897 \mathrm{~kg} /$ year or $8.05 \mathrm{~kg} / \mathrm{d}^{14}$. Dairy cows were randomly allocated to three ensiled RS with various yeast species including $S$. cerevisiae, $P$. kudriavzevii KKU20, and C. tropicalis KKU20 according to a $3 \times 3$ replicated Latin square design.

\section{Ensiling rice straw with yeast from rumen fluid}

The ruminal yeasts were obtained by isolating, screening, and identifying the rumen of crossbred ThaiHolstein Friesian dairy cattle ${ }^{8}$. The $P$. kudriavzevii KKU20 and C. tropicalis KKU20 were tested for their high-potential on in vitro study, which has an outstanding benefit for feed digestion and in vitro gas production ${ }^{15}$. The $S$. cerevisae was obtained from the commercial baker's yeast (Perfect yeast Co., Ltd, Ubon Ratchathani, Thailand). Isolated homogenous yeast suspension from rumen (about $10^{6}$ cells per $\mathrm{ml}$ ) were multiplied in media solution including $250 \mathrm{~g}$ molasses (Khon Kaen Dairy cooperative Co., Ltd., Khon Kaen, Thailand) plus $10 \mathrm{~g}$ urea per $1000 \mathrm{ml}$ of water. After that, the solution's pH was then modified using formic acid (L.C. industrial Co., Ltd, Nakhon Pathom, Thailand) to reach a final pH of $3.5^{2}$. Media solution directly into electromagnetic air compressor (Hailea aco-318 oxygen pump, Sagar aquarium ${ }^{\circledR}$, Gujarat, India) flushed with oxygen to complete respiration for maximum cell growth at 72 hours (final estimated yeast as $1 \times 10^{9} \mathrm{cfu} / \mathrm{ml}^{15}$. The media solution was mix on the RS ( 2:1 ratio) and adjusted with a moisture content of $650-750 \mathrm{~g} / \mathrm{kg}$ to provide sufficient ensilage conditions ${ }^{16}$. Fifteen kilograms of ensiled RS were put into plastic bags (size $24 \times 42$ inch, P.P Plastic Pagchong Co., Ltd, Nakhonrachasrima, Thailand), and sealed with a vacuum machine (Imaflex 1400W VC-921, Imarflex 
Industrial Co., Ltd., Bangkok, Thailand). To ensure anaerobic environment, the bags were securely sealed and fermented at room temperature for 14 days ${ }^{13}$.

\section{Feeding and samples collection}

The feeding trial lasted for 63 days ( 21 days/period with 3 periods); dairy cows were held in independent pens and individually fed roughage and concentrate diets at 07:00 and 16:00. Ensiled RS offered ad libitum for all cows. The experimental diet was formulated by using the KCF 2006 Program ${ }^{17}$. The ingredients and nutrient composition of ensiled RS and concentrate diet were provided in Table 1. During the experiment, mineral blocks and fresh water were accessible. The experiment was performed over 3 periods with double squares. The period lasted for 21 days, the first 14 days for treatment adjustments and the last 7 days for sample intake and collection assessment.

In the time of the feeding trial, orts were obtained and weights were collected every day, and the feeding rate was adjusted daily to yield orts between 50 to $100 \mathrm{~g} / \mathrm{kg}$ of intake. Individual voluntary feed determined consumption difference between the feed offered and orts. Around $5 \mathrm{~g} / \mathrm{kg}$ of the overall fresh fecal samples were split into two parts; the first part of each day for DM analysis and the second part were pooled at the end of each period. The pooled fecal samples $(500 \mathrm{~g})$ were stored at $-20^{\circ} \mathrm{C}$ until analysis. At $60^{\circ} \mathrm{C}$, composite samples were dried, pressed through a steel filter of $1 \mathrm{~mm}$ for grinding (Wiley mill, Arthur H. Thomas Co., Ltd., Philadelphia, PA,USA), and then analyzed for dry matter (DM; ID 967.03), ash (ID 492.05), ether extract (EE; ID 455.08), crude protein (CP; ID 984.13) content ${ }^{18}$, NDF, acid detergent fiber (ADF) ${ }^{19}$, and acid-insoluble ash (AIA) ${ }^{20}$. Body weights were measured every period. The calculation of metabolizable energy $(\mathrm{ME})$ was based on the equation defined by ${ }^{21}: \mathrm{ME}(\mathrm{MJ} / \mathrm{kg} \mathrm{DM})=$ $0.82 \times[2.4 \times \mathrm{CP}+3.9 \mathrm{EE} \times 1.8 \times$ the rest of the $\mathrm{OM}] \times$ in vitro organic matter digestibility (IVOMD), where $\mathrm{CP}, \mathrm{EE}$, and $\mathrm{OM}$ are in $\mathrm{g}$ per $\mathrm{kg}$ of $\mathrm{DM}$ and IVOMD with the mean values received from our recent in vitro study with mean values of $682.5 \mathrm{~g} / \mathrm{kg} \mathrm{DM}^{13}$. The $10 \mathrm{~g}$ of fresh silage was blended with $90 \mathrm{ml}$ of sterilized water and stored at $4{ }^{\circ} \mathrm{C}^{22}$. The $\mathrm{pH}$ of the ensiled RS was measured by a pH meter using coldwater extracts (Hanna HI-8424 Portable pH/ORP Meter, Woonsocket, USA) according to ${ }^{23}$. Silage fluid subsamples were centrifuged for 15 minutes at 16,000 rpm and the liquid above the solid residue was filtered using a 0.45 micron syringe filter. High-performance liquid chromatography (HPLC) devices (Shimadzu LC-20A, Shimadzu Industrial Systems Co., Ltd, Kyoto, Japan) were used to conduct lactic acid $(\mathrm{LA})$, acetic acid $\left(\mathrm{C}_{2}\right)$, propionic acid $\left(\mathrm{C}_{3}\right)$, and butyric acid $\left(\mathrm{C}_{4}\right)$ analyses ${ }^{24}$. The ammonia-nitrogen $\left(\mathrm{NH}_{3}{ }^{-}\right.$ $\mathrm{N})$ concentration was calculated according to the Kjeldahl process ${ }^{18}$.

Jugular blood and rumen fluid samples were obtained at 0 and 4 hours after feeding on the last day of each period. A blood sample (approximately $10 \mathrm{~mL}$ ) was obtained in tubes containing $12 \mathrm{mg}$ of ethylene diamine tetra-acetic acid (EDTA) from the jugular vein. The plasma was isolated by centrifugation for $10 \mathrm{~min}$ at $500 \times \mathrm{g}$ and preserved at $-20 \otimes \mathrm{C}$ until blood urea-nitrogen (BUN) analysis, according to Crocker

25 . Approximately $200 \mathrm{~mL}$ of rumen fluid was collected from the rumen by a stomach tube connected to a vacuum pump. Rumen fluid was assessed immediately by the pH meter (Hanna Instruments HI 8424 microcomputer, Hanna Instruments (Thailand) Ltd, Bangkok, Thailand) for determining the $\mathrm{pH}$ and 
temperature. Rumen fluid samples were then filtered through 4 cheesecloth layers. A fluid sample containing $5 \mathrm{~mL}$ of $1 \mathrm{~mol} / \mathrm{L}$ of $\mathrm{H}_{2} \mathrm{SO}_{4}$ applied to $45 \mathrm{~mL}$ of rumen fluid was put into the bottle. The rumen fluid mixture was centrifuged for 15 min at $16,000 \times \mathrm{g}$ and used for analyzing the $\mathrm{NH}_{3}-\mathrm{N}(A O A C, 1998)$ and volatile fatty acid (VFA) (gas chromatography, Model HP6890-Hewlett, NY, USA; ${ }^{26}$. Methane $\left(\mathrm{CH}_{4}\right)$ production was calculated using VFA profiles following the equation $\mathrm{CH}_{4}(\mathrm{~g} / \mathrm{d})=0.45 \times \mathrm{C}_{2}(\mathrm{mmol} / \mathrm{L})-$ $0.275 \times \mathrm{C}_{3}(\mathrm{mmol} / \mathrm{L})+0.40 \times \mathrm{C}_{4}(\mathrm{mmol} / \mathrm{L})$ according to Moss et al. ${ }^{27}$.. Ruminal bacteria, protozoa, and fungal zoospores were numbered under a hemocytometer using the direct counting method ${ }^{28}$.

During the last 7 days of each experimental period, milk samples were taken according to the yield for morning and afternoon milking, preserved with 2-bromo-2 nitropropane-1, 3-dial, and stored at 4 『C until analysis by using Milko-Scan (Foss Electric, Hillerod, Demark) for fat, true protein, lactose, total solids (TS), and solids-not-fat (SNF) content. Milk urea nitrogen (MUN) was estimated by the diacetyl monoxime method using UV/Vis-spectrophotometer (PG Instruments Ltd., London, UK) according to Ochei and Kolkhtar ${ }^{29}$. Fat, protein, lactose, TS, and SNF concentrations were measured as weighted media depending on morning and afternoon milk yields per each test day by infrared methods using Milko-Scan 33 (Foss Electric, Hillerod, Demark). Yields of $4.0 \%$ fat-corrected milk (FCM) were calculated according to ${ }^{30}$,Gaines ${ }^{31}$, while yields of energy-corrected (ECM) were calculated as described by Krause and Combs 32 . For each cow and period, feed conversion efficiencies were determined by dividing the average yield of actual milk and ECM by the respective dry matter intake (DMI) and digestible protein per yield of actual milk ${ }^{33}$.

\section{Statistical analysis}

All data from the experiment were analyzed according to a $3 \times 3$ replicated Latin square design using the GLM procedure ${ }^{34}$ according to the model:

$Y i j k l=\mu+S I+M i(l)+A j+P k+\varepsilon i j k l$

where $Y i j k$, observation from cow $j$, receiving ensiled RS $i$, in period $k, \mu$, the overall of mean, $S$, the effect of square $(I=1,2)$; Mi, effect of yeast species in RS silage $(i=1,2,3)$; $A j$, the effect of cows $(j=1,2,3,4,5$, $6) ; P k$, the effect of period $(k=1,2,3)$; and $\varepsilon i j k$, the residual effect. Significant differences between individual means were evaluated using the Duncan's multiple comparison tests when a significant $(\mathrm{P}<$ 0.05 ) effect was detected ${ }^{35}$. Standard errors of means were calculated from the residual mean squares in the analysis of variance.

\section{Declarations}

\section{Acknowledgements}

The authors would like to express our sincere thanks to the Royal Golden Jubilee Ph.D. Scholarship Program, Thailand Research Fund (TRF Grant No PHD/0132/2560) and the Increase Production 
Efficiency and Meat Quality of Native Beef and Buffalo Research Group, Khon Kaen University for their kind financial support. Thanks to the Tropical Feed Resources Research and Development Center (TROFEC), Department of Animal Science, Faculty of Agriculture and Khon Kaen University, KKU for the use of research facilities.

\section{Author contributions}

C. Suntara, A. Cherdthong and S. Uriyapongson: Investigation, Methodology; C. Suntara, A. and Cherdthong: Data curation, Formal analysis, Software, and Project administration, Conceptualization, Methodology, and Project administration, Funding acquisition; C. Suntara A. Cherdthong, and S. Uriyapongson: Resources, Supervision, Validation; Visualization; C. Suntara: Roles/Writing - original draft; C. Suntara, A. Cherdthong, M. Wanapat and P. Chanjula: Writing - review \& editing. All authors have read and agreed to the published version of the manuscript.

\section{Competing interests}

The authors declare no conflict of interest.

\section{References}

1. Mohammed, S. F., Mahmood, F. A. \& Abas, E. R. A review on effects of yeast (Saccharomyces cerevisiae) as feed additives in ruminants performance. Journal of Entomology and Zoology Studies 6, 629-635 (2018).

2. Khampa, S., Chaowarat, P., Singhalert, R. \& Wanapat, M. Supplementation of yeast fermented cassava chip as a replacement concentrate on rumen fermentation efficiency and digestibility on nutrients in cattle. Asian Journal of Animal Science 3, 18-24 (2009).

3. Foiklang, S. et al. In vitro gas kinetics and digestibility as influenced by yeast media solution ratios and physical forms of rice straw. KHON KAEN AGR. J. 45, 74-79 (2017).

4. Promkot, C., Wanapat, M. \& Mansathit, J. Effects of yeast fermented-cassava chip protein (YEFECAP) on dietary intake and milk production of Holstein crossbred heifers and cows during pre-and postpartum period. Livestock Science 154, 112-116 (2013).

5. Wanapat, M., Boonnop, K., Promkot, C. \& Cherdthong, A. Effects of alternative protein sources on rumen microbes and productivity of dairy cows. Maejo International Journal of Science and Technology 5, 13 (2011).

6. Wang, Z. et al. Evaluation of different yeast species for improving in vitro fermentation of cereal straws. Asian-Australasian journal of animal sciences 29, 230 (2016).

7. Holtshausen, L. \& Beauchemin, K. Supplementing barley-based dairy cow diets with Saccharomyces cerevisiae. The Professional Animal Scientist 26, 285-289 (2010). 
8. Suntara, C. \& Cherdthong, A. Screening and isolation of potential yeast from rumen fluids and optimization of biomass and cellulase production Doctoral seminar course thesis, Khon Kaen University, (2019).

9. Dashko, S., Zhou, N., Compagno, C. \& Piškur, J. Why, when, and how did yeast evolve alcoholic fermentation? FEMS yeast research 14, 826-832 (2014).

10. Van Urk, H., Voll, W. L., Scheffers, W. A. \& Van Dijken, J. P. Transient-state analysis of metabolic fluxes in Crabtree-positive and Crabtree-negative yeasts. Appl. Environ. Microbiol. 56, 281-287 (1990).

11. Wardrop, F., Liti, G., Cardinali, G. \& Walker, G. Physiological responses of Crabtree positive and Crabtree negative yeasts to glucose upshifts in a chemostat. Annals of microbiology $54,103-114$ (2004).

12. Sarawan, S., P. Mahakhan, S. Jindamorakot, K. Vichitphan, S. Vichitphan and J. Sawaengkaew. Candida konsanensis sp. nov., a new yeast species isolated from Jasminum adenophyllum in Thailand with potentially carboxymethyl cellulase-producing capability. World. J. Microb. Biot. 29, 1481-1486 (2013).

13. Suntara, C. \& Cherdthong, A. Comparison effects of ruminal Crabtree negative yeasts and Crabtree positive yeasts for improving ensilage rice straw quality and ruminal digestion using in vitro gas production Doctoral seminar course thesis, Khon Kaen University, (2020).

14. Galukande, E. et al. Cross-breeding cattle for milk production in the tropics: achievements, challenges and opportunities. Recursos Geneticos Animales (2013).

15. Suntara, C., Cherdthong, A., Uriyapongson, S., Wanapat, M. \& Chanjula, P. Comparison Effects of Ruminal Crabtree-Negative Yeasts and Crabtree-Positive Yeasts for Improving Ensiled Rice Straw Quality and Ruminal Digestion Using In Vitro Gas Production. J. Fungi 6, 1-20, doi:https://doi.org/10.3390/jof6030109 (registering DOI) (2020).

16. Yitbarek, M. B. \& Tamir, B. Silage additives. Open Journal of Applied Sciences 2014 (2014).

17. Dairy Feed and Least Cost Feed Formulation Program (Department of Animal Science, Faculty of Agriculture, Khon Kaen Universitry., 2006).

18. AOAC, A. O. O. A. C. (Arlington Virginia, 1998).

19. Van Soest, P., Robertson, J. \& Lewis, B. Methods for dietary fiber, neutral detergent fiber, and nonstarch polysaccharides in relation to animal nutrition. Journal of dairy science $74,3583-3597$ (1991).

20. Van Keulen, J. \& Young, B. Evaluation of acid-insoluble ash as a natural marker in ruminant digestibility studies. Journal of Animal Science 44, 282-287 (1977).

21. Robinson, P., Givens, D. \& Getachew, G. Evaluation of NRC, UC Davis and ADAS approaches to estimate the metabolizable energy values of feeds at maintenance energy intake from equations utilizing chemical assays and in vitro determinations. Animal Feed Science and Technology 114, $75-$ 90 (2004).

22. Cai, Y., Benno, Y., Ogawa, M. \& Kumai, S. Effect of applying lactic acid bacteria isolated from forage crops on fermentation characteristics and aerobic deterioration of silage. Journal of dairy science 82 , 
520-526 (1999).

23. Cai, Y. Analysis method for silage. Japanese Society of Grassland Science, editors. Field and laboratory methods for grassland science. Tokyo, Japan: Tosho Printing Co. Ltd, 279 (2004).

24. Prueksatrakul, T., Phoopra-in, P., Jaiyen, P., Vilairat, P. \& Jantivas, R. in The National and International Conference \& Research Presentation 2015 "Create and Development to Approach ASEAN Community II. 155-162.

25. Crocker, C. Rapid determination of urea nitrogen in serum or plasma without deproteinization. The American journal of medical technology 33, 361 (1967).

26. Yamamoto-Osaki, T., Kamiya, S., Sawamura, S., Kai, M. \& Ozawa, A. Growth inhibition of Clostridium difficile by intestinal flora of infant faeces in continuous flow culture. Journal of medical microbiology 40, 179-187 (1994).

27. Moss, A. R., Jouany, J.-P. \& Newbold, J. in Annales de zootechnie. 231-253 (EDP Sciences).

28. Galyean, M. Laboratory procedure in animal nutrition research. Department of Animal and Life Science. New Mexico State University, USA, 188 (1989).

29. Ochei, J. \& Kolkhtar, A. in Bacteriology: Medical Laboratory Science, theory and practice (eds Bulakh P.M. \& Deshmukh S.) 525-752 (Tata McGraw-Hill publishing Company limited, 2000).

30. Rafferty, D. et al. Feeding a marine-based rumen buffer increases milk production and decreases time of low reticulo-rumen $\mathrm{pH}$ in grazing dairy cows offered perennial ryegrass-based pasture. Animal Feed Science and Technology 256, 114255 (2019).

31. Gaines, W. An efficiency formula for dairy cows. Science 67, 353-354 (1928).

32. Krause, K. M. \& Combs, D. K. Effects of forage particle size, forage source, and grain fermentability on performance and ruminal $\mathrm{pH}$ in midlactation cows. Journal of dairy science $86,1382-1397$ (2003).

33. Paula, E. et al. Effects of replacing soybean meal with canola meal or treated canola meal on ruminal digestion, omasal nutrient flow, and performance in lactating dairy cows. Journal of dairy science 101, 328-339 (2018).

34. User's Guide: Statistic v. Version 6 (Cary, NC., 1989).

35. Steel, R. G. \& Torrie, J. H. Principles and Procedures of Statistics McGraw-Hill Book Co. Inc., New York 633 (1980).

36. NRC. NRC. 2001. Nutrient requirements of dairy cattle 7, 381 (2001).

37. Ilmén, M. et al. High level secretion of cellobiohydrolases by Saccharomyces cerevisiae. Biotechnology for biofuels 4, 30 (2011).

38. Ávila, C. \& Carvalho, B. Silage fermentation-updates focusing on the performance of microorganisms. Journal of Applied Microbiology 128, 966-984 (2020).

39. Jianxin, L. \& Jun, G. Ensiling crop residues. FAO Animal Production and Health Paper (FAO) (2002).

40. Kim, S. \& Adesogan, A. Influence of ensiling temperature, simulated rainfall, and delayed sealing on fermentation characteristics and aerobic stability of corn silage. Journal of Dairy Science 89, 3122- 
$3132(2006)$.

41. Li, J., Shen, Y. \& Cai, Y. Improvement of fermentation quality of rice straw silage by application of a bacterial inoculant and glucose. Asian-Australasian Journal of Animal Sciences 23, 901-906 (2010).

42. Gunun, P., Wanapat, M. \& Anantasook, N. Effects of Physical Form and Urea Treatment of Rice Straw on Rumen Fermentation, Microbial Protein Synthesis and Nutrient Digestibility in Dairy Steers. AsianAustralasian Journal of Animal Sciences 26, 1689-1697, doi:DOI:

https://doi.org/10.5713/ajas.2013.13190 (2013).

43. Wanapat, M., Kang, S., Hankla, N. \& Phesatcha, K. Effect of rice straw treatment on feed intake, rumen fermentation and milk production in lactating dairy cows. African Journal of Agricultural Research 8, 677-1687, doi:DOI: 10.5897/AJAR2013.6732 (2013).

44. Jackson, M. Rice straw as livestock feed. World Animal Review 23, 79-81 (1977).

45. Sarnklong, C., Cone, J., Pellikaan, W. \& Hendriks, W. Utilization of rice straw and different treatments to improve its feed value for ruminants: a review. Asian-Australasian Journal of Animal Sciences 23, 680-692 (2010).

46. Aquino, D. et al. in Sustainable Rice Straw Management 111-129 (Springer, Cham, 2020).

47. Wachirapakorn, C., Pilachai, K., Wanapat, M., Pakdee, P. \& Cherdthong, A. Effect of ground corn cobs as a fiber source in total mixed ration on feed intake, milk yield and milk composition in tropical lactating crossbred Holstein cows. Animal Nutrition 2, 334-338 (2016).

48. Lunsin, R. Effect of oil palm meal on nutrient utilization and milk production in lactating dairy cows fed with urea-treated rice straw. Agriculture and Natural Resources 52, 285-289 (2018).

49. Dal Pizzol, J., Ribeiro-Filho, H., Quereuil, A., Le Morvan, A. \& Niderkorn, V. Complementarities between grasses and forage legumes from temperate and subtropical areas on in vitro rumen fermentation characteristics. Animal Feed Science and Technology 228, 178-185 (2017).

50. Polyorach, S. \& Wanapat, M. Improving the quality of rice straw by urea and calcium hydroxide on rumen ecology, microbial protein synthesis in beef cattle. Journal of animal physiology and animal nutrition 99, 449-456 (2015).

51. Khan, R. U. et al. Direct-fed microbial: beneficial applications, modes of action and prospects as a safe tool for enhancing ruminant production and safeguarding health. Int J Pharmacol 12, 220-231 (2016).

52. Rossi, F., Di Luccia, A., Vincenti, D. \& Cocconcelli, P. S. Effects of peptidic fractions from Saccharomyces cerevisiae culture on growth and metabolism of the ruminal bacteria Megasphaera elsdenii. Animal Research 53, 177-186 (2004).

53. Habeeb, A. A. M. Importance of yeast in ruminants feeding on production and reproduction. Ecology and Evolutionary Biology 2, 49 (2017).

54. Galvão, K. N. et al. Effect of feeding live yeast products to calves with failure of passive transfer on performance and patterns of antibiotic resistance in fecal Escherichia coli. Reproduction Nutrition Development 45, 427-440 (2005). 
55. Fonty, G. \& Chaucheyras-Durand, F. Effects and modes of action of live yeasts in the rumen. Biologia $61,741-750$ (2006).

56. Koatdoke, U., Cherdthong, A. \& Khampa, S. Supplementation levels of palm oil in yeast (Saccharomyces cerevisiae) culture fermented cassava pulp on rumen fermentation and average daily gain in crossbred native cattle. Pakistan Journal of Nutrition 10, 1115-1120 (2011).

57. Piškur, J. \& Compagno, C. Molecular mechanisms in yeast carbon metabolism. 333 ( Springer; 2014th Edition (May 6, 2014), 2014).

58. Gang, G. et al. The effect of lactic acid bacteria inoculums on in vitro rumen fermentation, methane production, ruminal cellulolytic bacteria populations and cellulase activities of corn stover silage. Journal of Integrative Agriculture 19, 838-847 (2020).

59. Matthews, C. et al. The rumen microbiome: a crucial consideration when optimising milk and meat production and nitrogen utilisation efficiency. Gut microbes 10, 115-132 (2019).

60. Castillo-González, A., Burrola-Barraza, M., Domínguez-Viveros, J. \& Chávez-Martínez, A. Rumen microorganisms and fermentation. Archivos de Medicina Veterinaria 46, 349-361 (2014).

61. Supapong, C. \& Cherdthong, A. Effect of Sulfur and Urea Fortification of Fresh Cassava Root in Fermented Total Mixed Ration on the Improvement Milk Quality of Tropical Lactating Cows. Veterinary Sciences 7, 98 (2020).

62. Dobson, H., Smith, R., Royal, M., Knight, C. \& Sheldon, I. The high-producing dairy cow and its reproductive performance. Reproduction in domestic animals 42, 17-23 (2007).

63. Kirkland, R. \& Gordon, F. The effects of milk yield and stage of lactation on the partitioning of nutrients in lactating dairy cows. Journal of Dairy Science 84, 233-240 (2001).

64. Xie, Y., Wu, Z., Wang, D. \& Liu, J. Nitrogen partitioning and microbial protein synthesis in lactating dairy cows with different phenotypic residual feed intake. Journal of animal science and biotechnology 10, 54 (2019).

65. Swanepoel, N., Robinson, P. \& Erasmus, L. J. Rumen microbial protein flow and plasma amino acid concentrations in early lactation multiparity Holstein cows fed commercial rations, and some relationships with dietary nutrients. Livestock Science 190, 58-69 (2016).

66. Intanoo, M. et al. Isolation and screening of aflatoxin-detoxifying yeast and bacteria from ruminal fluids to reduce aflatoxin B1 contamination in dairy cattle feed. Journal of applied microbiology 125 , 1603-1613 (2018). 